\title{
Political Survival
}

Politicians and Public Policy

in Latin America 
California Series on Social Choice and Political Economy

Edited by Brian Barry, Robert H. Bates, and Samuel L. Popkin

1. Markets and States in Tropical Africa: The Political Basis of Agricultural Policies ROBERT H. BATES

2. Political Economics JAMES E. ALT AND K. ALEC CHRYSTAL

3. Abortion and the Politics of Motherhood KRISTIN LUKER

4. Hard Choices: How Women Decide about Work, Career, and Motherhood KATHLEEN GERSON

5. Regulatory Policy and the Social Sciences ROGER NOLL, editor

6. Reactive Risk and Rational Action: Managing Moral Hazard in Insurance Contracts CAROL A. HEIMER

7. Post-Revolutionary Nicaragua: State, Class, and the Dilemmas of Agrarian Policy FORREST D. COLBURN

8. Essays on the Political Economy of Rural Africa ROBERT H. BATES

9. Peasants and King in Burgundy: Agrarian Foundations of French Absolutism HILTON L. ROOT

10. The Causal Theory of Justice KAROL SOLTAN

11. Principles of Group Solidarity MICHAEL HECHTER

12. Political Survival: Politicians and Public Policy in Latin America BARRY AMES 


\section{Political Survival}

Politicians and Public Policy

in Latin America

Barry Ames

University of California Press

Berkeley / Los Angeles / London 
University of California Press

Berkeley and Los Angeles, California

University of California Press, Ltd.

London, England

(C) 1987 by

The Regents of the University of California

Library of Congress Cataloging-in-Publication Data

Ames, Barry.

Political survival.

(California series on social choice and political economy)

Bibliography: $p$.

Includes index.

1. Latin America-Politics and government-19482. Politics, Practical. 3. Government spending policyLatin America. I. Title. II. Series.

JL976.A44 $1987 \quad 320.98$

86-24921

ISBN 0-520-05974-3 (alk. paper)

Printed in the United States of America

$\begin{array}{lllllllll}1 & 2 & 3 & 4 & 5 & 6 & 7 & 8 & 9\end{array}$ 
To my mother and late father 
